\title{
Polyanxanthone A, B and C, three xanthones from the wood trunk of Garcinia polyantha Oliv.
}

\author{
Gabin Nselapi Louh ${ }^{\text {a }}$, Alain Meli Lannang ${ }^{\text {a,*, }}$ Celine Djama Mbazoa ${ }^{\text {a }}$, \\ Jean Gustave Tangmouo a, Justin Komguem a, Paula Castilho ${ }^{\text {b }}$, \\ Fernande Ngounou Ngninzeko ${ }^{a}$, Naz Qamar ${ }^{c}$, David Lontsi ${ }^{\text {a,* }}$, \\ Muhammad Iqbal Choudhary ${ }^{\mathrm{c}}$, Beiban Luc Sondengam ${ }^{\mathrm{a}}$ \\ ${ }^{a}$ Department of Organic Chemistry, Faculty of Science, University of Yaoundé I, P.O. Box 812, Yaoundé, Cameroon \\ ${ }^{\mathrm{b}}$ Centro de Quimica da Madeira, Departamento de Quimica, Universidade da Madeira, Campus Universitario da Penteada, 9000-390 Funchal, Portugal \\ ${ }^{c}$ International Center for Chemical and Biological Sciences, H.E.J. Research Institute of Chemistry, University of Karachi, Karachi 75270, Pakistan
}

Received 19 July 2007; received in revised form 30 September 2007

Available online 26 November 2007

\begin{abstract}
Three xanthones, polyanxanthone A (1), B (2) and C (3) have been isolated from the methanol extract of the wood trunk of Garcinia polyantha, along with five known xanthones: 1,3,5-trihydroxyxanthone (4); 1,5-dihydroxyxanthone (5); 1,3,6,7-tetrahydroxyxanthone (6); 1,6-dihydroxy-5-methoxyxanthone (7) and 1,3,5,6-tetrahydroxyxanthone (8). Their structures were determined by means of 1Dand 2D-NMR techniques. Some of the above compounds were screened for their anticholinesterase activity on acetylcholinesterase (AChE) and butyrylcholinesterase (BChE) enzymes.
\end{abstract}

(C) 2007 Elsevier Ltd. All rights reserved.

Keywords: Garcinia polyantha; Polyanxanthone A; Polyanxanthone B; Polyanxanthone C; Prenyloxyxanthones; Anticholinesterase

\section{Introduction}

The genus Garcinia of the Guttiferae family is well known to be a rich source of bioactive isoprenylated xanthones (Kanda et al., 2006; Deachathai et al., 2006; Komguem et al., 2005) and benzophenones (Nilar et al., 2005; Williams et al., 2003). In continuation of our search for bioactive substances from Garcinia species, we have investigated the methanol extract of the wood trunk of Garcinia Polyantha Oliv, a tree distributed in the lowland tropical rainforest of west, east and central Africa (Ampofo and Waterman, 1986; Brehaut, 1975). This investigation led to the isolation of three new xanthones (1-3) and five

\footnotetext{
* Corresponding authors. Tel.: +237 775348 30; fax: +237 22229116 (A.M. Lannang), tel.: +237 7776 2780; fax: +237 22229116 (D. Lontsi). E-mail addresses: alainmeli@yahoo.com (A.M. Lannang), dlontsi2000@yahoo.co.uk (D. Lontsi).
}

known xanthones (4-8). We report herein, the structure elucidation of the above compounds along with their anticholinesterase activities.

\section{Results and discussion}

The methanol extract of powder wood trunk of G. polyantha was separated by silica gel column chromatography to give three new xanthone derivatives named polyanxanthone A (1), B (2) and C (3) along with five known xanthones: 1,3,5-trihydroxyxanthone (4) (Zhang et al., 2002); 1,5-dihydroxyxanthone (5) (Nkengfack et al., 2002); 1,3,6,7-tetrahydroxyxanthone (6) (Carpenter et al., 1969); 1,6-dihydroxy-5-methoxyxanthone (7) (Zhang et al., 2002) and 1,3,5,6-tetrahydroxyxanthone (8) (Frahm and Chandhuri, 1979).

The following spectral data showed that all the new xanthones have a prenyloxy groups at C-1 and C-5. UV 
absorption of these compounds showed two strong bands at $\lambda_{\max } 240-248$ and $254-266 \mathrm{~nm}$, a medium bands at $\lambda_{\max }$ $302-312 \mathrm{~nm}$, and weak broad bands at $\lambda_{\max } 352-390 \mathrm{~nm}$ indicated the conjugated chromophore systems (Ito et al., 2003). The IR spectra showed evenly bands at $v_{\max } 1656-$ 1665 and $1560-1601 \mathrm{~cm}^{-1}$ (Meli et al., 2005) suggesting a carbonyl and an aromatic double bonds, respectively.

Polyanxanthone A (1) was isolated as a whitish crystal, $\mathrm{mp}: 135-137^{\circ} \mathrm{C}$. The HREIMS spectroscopy of this compound gave the molecular ion peak at $\mathrm{m} / \mathrm{z} 448.2277$ (Calc. 448.2212) corresponding to $\mathrm{C}_{28} \mathrm{H}_{32} \mathrm{O}_{5}$ formula. The ${ }^{1} \mathrm{H}$ NMR spectrum showed signals due to three prenyloxy groups, respectively at $\left[\delta_{\mathrm{H}} 4.63\left(2 \mathrm{H}, \mathrm{d}, J=6.3 \mathrm{~Hz}, \mathrm{H}-1^{\prime}\right)\right.$, $5.57\left(1 \mathrm{H}, \mathrm{t}, J=6.3 \mathrm{~Hz}, \mathrm{H}-2^{\prime}\right), 1.76\left(3 \mathrm{H}, \mathrm{s}, \mathrm{H}-5^{\prime}\right), 1.80$ $\left.\left(3 \mathrm{H}, \mathrm{s}, \mathrm{H}-4^{\prime}\right)\right] ;\left[\delta_{\mathrm{H}} 4.57\left(2 \mathrm{H}, \mathrm{d}, J=6.8 \mathrm{~Hz}, \mathrm{H}-1^{\prime \prime}\right), 5.52\right.$ $\left(1 \mathrm{H}, \mathrm{t}, J=6.8 \mathrm{~Hz}, \mathrm{H}-2^{\prime \prime}\right), 1.72\left(3 \mathrm{H}, \mathrm{s}, \mathrm{H}-5^{\prime \prime}\right), 1.77(3 \mathrm{H}, \mathrm{s}$, $\left.\left.\mathrm{H}-4^{\prime \prime}\right)\right]$ and $\left[\delta_{\mathrm{H}} 4.70\left(2 \mathrm{H}, \mathrm{d}, J=6.6 \mathrm{~Hz}, \mathrm{H}-1^{\prime \prime \prime}\right), 5.62(1 \mathrm{H}\right.$, $\left.\mathrm{t}, J=6.6 \mathrm{~Hz}, \mathrm{H}-2^{\prime \prime \prime}\right), 1.75\left(3 \mathrm{H}, \mathrm{s}, \mathrm{H}-5^{\prime \prime \prime}\right), 1.80(3 \mathrm{H}, \mathrm{s}, \mathrm{H}-$ $\left.4^{\prime \prime \prime}\right)$ ], as three substituents of xanthone nucleus. Further more, an $\mathrm{ABX}$ type signals, a lower field signal at $\delta_{\mathrm{H}}$ $7.84(1 \mathrm{H}, \mathrm{dd}, J=7.8$ and $1.4 \mathrm{~Hz})$ was assignable to $\mathrm{H}-8$, which was affected by deshielding due to $9-\mathrm{C}=\mathrm{O}$, and two others signals at $\delta_{\mathrm{H}} 7.19(1 \mathrm{H}, \mathrm{t}, J=7.8)$ and $\delta_{\mathrm{H}} 7.14$ $(1 \mathrm{H}, \mathrm{dd}, J=7.8$ and $1.4 \mathrm{~Hz})$ attributed to $\mathrm{H}-7$ and $\mathrm{H}-6$, respectively. The remaining signals observed as meta-coupled aromatic proton at $\delta_{\mathrm{H}} 6.60(1 \mathrm{H}, \mathrm{d}, J=2.2 \mathrm{~Hz})$ and $\delta_{\mathrm{H}} 6.34(1 \mathrm{H}, \mathrm{d}, J=2.2 \mathrm{~Hz})$ were assignable to $\mathrm{H}-2$ and $\mathrm{H}-4$, respectively. HMBC correlations (Table 1) from 9$\mathrm{C}=\mathrm{O}, \mathrm{C}-6, \mathrm{C}-10 \mathrm{a}$ to $\mathrm{H}-8$, from C-8, C-5, C-10a to $\mathrm{H}-6$, from C-5, C-8a to H-7, from C-9a, C-4 to $\mathrm{H}-2$ and from C-9a, C-2 to H-4 firmly confirm the location of different aromatic protons. As far as, $\mathrm{C}-\mathrm{H}$ long range correlations in the HMBC spectrum (Table 1) from oxygenated quaternary carbon $\mathrm{C}-1$ to $\mathrm{H}-1^{\prime}$, from $\mathrm{C}-3$ to $\mathrm{H}-1^{\prime \prime}$ and from $\mathrm{C}-5$ to $\mathrm{H}-1^{\prime \prime \prime}$ indicated the assignment of the location of the three prenyl groups. On the basis of these data, the structure of polyanxanthone. A was determined to be (1), identified as 1,3,5-triprenyloxyxanthone.

Polyanxanthone B (2) was obtained as a white crystal, $\mathrm{mp}: 139.9-140{ }^{\circ} \mathrm{C}$. The molecular formula was determined as $\mathrm{C}_{23} \mathrm{H}_{24} \mathrm{O}_{5}$ from the HREIMS, $m / z 364.168$ (Calc. 364.1675). It is ${ }^{1} \mathrm{H}$ NMR spectrum was shown to be quite similar to that of (1), with characteristic resonances which again could be associated with two prenyloxy moieties, respectively at $\left[\delta_{\mathrm{H}} 4.68\left(2 \mathrm{H}, \mathrm{d}, J=5.7 \mathrm{~Hz}, \mathrm{H}-1^{\prime}\right), 5.57\right.$ $\left(1 \mathrm{H}, \mathrm{t}, J=5.7 \mathrm{~Hz}, \mathrm{H}-2^{\prime}\right), 1.80\left(3 \mathrm{H}, \mathrm{s}, \mathrm{H}-4^{\prime}\right), 1.78(3 \mathrm{H}, \mathrm{s}$, $\left.\left.\mathrm{H}-5^{\prime}\right)\right]$ and $\left[\delta_{\mathrm{H}} 4.70\left(2 \mathrm{H}, \mathrm{d}, J=4.2 \mathrm{~Hz}, \mathrm{H}-1^{\prime \prime}\right), 5.62(1 \mathrm{H}\right.$, $\left.\mathrm{t}, J=4.2 \mathrm{~Hz}, \mathrm{H}-2^{\prime \prime}\right), 1.78\left(3 \mathrm{H}, \mathrm{s}, \mathrm{H}-4^{\prime \prime}\right), 1.74(3 \mathrm{H}, \mathrm{s}, \mathrm{H}-$ $\left.\left.5^{\prime \prime}\right)\right]$, and three aromatic protons $\left[\delta_{\mathrm{H}} 7.17(1 \mathrm{H}, \mathrm{dd}, J=7.8\right.$ and $1.6 \mathrm{~Hz}, \mathrm{H}-6), 7.21(1 \mathrm{H}, \mathrm{t}, J=7.8 \mathrm{~Hz}, \mathrm{H}-7)$ and 7.85 $(1 \mathrm{H}, \mathrm{dd}, J=7.8$ and $1.6 \mathrm{~Hz}, \mathrm{H}-8)]$. These were observed except for the appearance of new aromatic proton $\mathrm{ABX}$ system on ring $\mathrm{C}$ at $\delta_{\mathrm{H}} 6.77(1 \mathrm{H}, \mathrm{dd}, J=8.4$ and $1.2 \mathrm{~Hz}$, $\mathrm{H}-2), 7.14(1 \mathrm{H}, \mathrm{dd}, J=8.4$ and $1.2 \mathrm{~Hz}, \mathrm{H}-4)$ and 7.56 $(1 \mathrm{H}, \mathrm{t}, J=8.4 \mathrm{~Hz}, \mathrm{H}-3)$, and the lack of a typical prenyloxy moiety aforementioned in compound (1). Examination of the contour plot of an HMBC experiment (Table 1) then revealed that the ring A of (2) was identical to that of polyanxanthone $\mathrm{A}$ and characterized with one prenyloxy group at C-5. Therefore, polyanxanthone B (2) was identified as 1,5-diprenyloxyxanthone.

Polyanxanthone C (3) was isolated as yellow oil. This compound was showed to have the molecular formula $\mathrm{C}_{28} \mathrm{H}_{32} \mathrm{O}_{4}$ by HREIMS which showed the $[\mathrm{M}+]$ ion peak at $\mathrm{m} / z$ 432.1683 (Calc. 432.1679). The ${ }^{1} \mathrm{H}$ NMR features were similar to those of (2), except for the appearance of prenyl group at $\delta_{\mathrm{H}} 3.45(2 \mathrm{H}, \mathrm{d}, J=7.2 \mathrm{~Hz}), 5.30(1 \mathrm{H}, \mathrm{t}$, $J=7.2 \mathrm{~Hz}), 1.71(3 \mathrm{H}, \mathrm{s})$ and $1.74(3 \mathrm{H}, \mathrm{s})$ instead of an aromatic proton appearing at $\delta_{\mathrm{H}} 6.77$ in ring $\mathrm{C}$ of (2). The lack of $\mathrm{ABX}$ system aforenamed on (2) and the presence of two aromatic protons ortho-coupled firmly indicated that $\mathrm{H}-2$ was substituted by a new prenyl moiety. This hypothesis was confirmed after recording of HMBC and NOESY experiments showing on one side the expected long range correlation between $\mathrm{H}-1^{\prime \prime}$ of prenyl group and $\mathrm{C}-1, \mathrm{C}-2$ and C-3 (Table 1) together with the strong nuclear overhauser effects between $\mathrm{H}-1^{\prime} / \mathrm{H}-1^{\prime \prime}$, and in the other side the strong nuclear overhauser between $\mathrm{H}-3 / \mathrm{H}-4, \mathrm{H}-3 / \mathrm{H}-2^{\prime \prime}$ and $\mathrm{H}-1^{\prime \prime \prime} / \mathrm{H}-6$ (Fig. 1). These results indicated the structure of polyanxanthone $\mathrm{C}(\mathbf{3})$, identified as 1,5-prenyloxy-2-(3methylbut-2-enyl)xanthone.

\subsection{Anticholinesterase activity}

Compounds $1,2,4,5$ and 7 were screened for their cholinesterase inhibitory potential. The compounds $\mathbf{4 , 5}$ and 7 showed significant inhibition against $\mathrm{BChE}$ with an $\mathrm{IC}_{50}$ value of $93.0,2.54$ and $74.4 \mu \mathrm{M}$, respectively, while compound 2 showed significant inhibition against both AChE $\left(\mathrm{IC}_{50}=46.3 \mu \mathrm{M}\right)$ and $\mathrm{BChE}\left(\mathrm{IC}_{50}=25.5 \mu \mathrm{M}\right)$ compared to the standard, galantamine $\left(\mathrm{IC}_{50}=0.5 \mu \mathrm{M}\right.$ and $8.5 \mu \mathrm{M}$, respectively). Compound 1 showed $41.8 \%$ and $7.0 \%$ inhibition against $\mathrm{AChE}$ and $\mathrm{BChE}$, respectively, at the concentration of $0.2 \mathrm{mM}$.

\section{Experimental}

\subsection{General procedure}

The melting points were determined on a micro melting point apparatus (Yanaco MP-S3 apparatus) and are uncorrected. Infrared spectra were obtained on a JASCO A-302 spectrophotometer using $\mathrm{KBr}$ pellets. Ultraviolet spectra were recorded on a Shimadzu UV 240 spectrophotometer in methanol. Mass spectra (EI and HREIMS) were measured in an electron impact mode on Varian MAT 312 spectrometers. The ${ }^{1} \mathrm{H}$ NMR spectra were registered on a Bruker Avance AMX 500 NMR spectrometer with tetramethylsilane (TMS) as an internal standard; while ${ }^{13} \mathrm{C}$ NMR spectra were recorded on a Bruker Avance AMX 500 NMR spectrometer operating at $125 \mathrm{MHz}$ using $\mathrm{CDCl}_{3}$ as solvent. Methyl, methylene and methine carbons were distinguished by DEPT experiments. Homonuclear 
Table 1

${ }^{1} \mathrm{H}$ and ${ }^{13} \mathrm{C}$ NMR data of polyanxanthone $\mathrm{A}(\mathbf{1}), \mathrm{B}(\mathbf{2})$ and $\mathrm{C}(\mathbf{3})(500,125 \mathrm{MHz})$ in $\mathrm{CDCl}_{3}$

\begin{tabular}{|c|c|c|c|c|c|c|c|c|c|}
\hline \multirow[t]{2}{*}{ Position } & \multicolumn{3}{|l|}{1} & \multicolumn{3}{|l|}{2} & \multicolumn{3}{|l|}{3} \\
\hline & ${ }^{1} \mathrm{H}(\mathrm{m}, \mathrm{J}(\mathrm{Hz})$ & ${ }^{13} \mathrm{C}$ & НМBC & ${ }^{1} \mathrm{H}(\mathrm{m}, \mathrm{J}(\mathrm{Hz})$ & ${ }^{13} \mathrm{C}$ & НМBC & ${ }^{1} \mathrm{H}(\mathrm{m}, \mathrm{J}(\mathrm{Hz})$ & ${ }^{13} \mathrm{C}$ & НMBC \\
\hline 1 & & 161.1 & & & 159.6 & & & 156.2 & \\
\hline 2 & $6.60(\mathrm{~d}, 2.2)$ & 93.6 & $\begin{array}{l}\text { C-3, C-9a, C-4, } \\
\text { C-1 }\end{array}$ & $\begin{array}{l}6.77(\mathrm{dd}, 8.4 \text { and } \\
1.2)\end{array}$ & 106.7 & $\begin{array}{l}\text { C-1, C-9a, C- } \\
4\end{array}$ & & 131.1 & \\
\hline 3 & & 163.9 & & $7.56(\mathrm{t}, 8.5)$ & 134.5 & C-1, C-4a & $7.50(\mathrm{~d}, 8.7)$ & 135.4 & C-1, C-4, C-2 \\
\hline 4 & $6.34(\mathrm{~d}, 2.2)$ & 96.9 & $\begin{array}{l}\text { C-3, C-9a, C-4a, } \\
\text { C-2 }\end{array}$ & $\begin{array}{l}7.14(\mathrm{dd}, 8.4 \text { and } \\
1.2)\end{array}$ & 110.2 & $\begin{array}{l}\text { C-2, C-9a, C- } \\
4 \mathrm{a}\end{array}$ & $7.31(\mathrm{~d}, 8.7)$ & 113.9 & C-9a, C-4a, C-3 \\
\hline $4 \mathrm{a}$ & & 159.6 & & & 157.9 & & & 155.9 & \\
\hline $10 \mathrm{a}$ & & 145.6 & & & 145.7 & & & 145.9 & \\
\hline 5 & & 147.1 & & & 147.3 & & & 147.4 & \\
\hline 6 & $\begin{array}{l}7.14(\mathrm{dd}, 7.8 \text { and } \\
1.4)\end{array}$ & 116.3 & C-10a, C-8, C-5 & $\begin{array}{l}7.17(\mathrm{dd}, 7.8 \text { and } \\
1.6)\end{array}$ & 116.6 & $\begin{array}{l}\text { C-8, C-5, C- } \\
10 \mathrm{a}\end{array}$ & $\begin{array}{l}7.18(\mathrm{dd}, 7.1 \text { and } \\
1.9)\end{array}$ & 116.7 & C-10a, C-8 \\
\hline 7 & $7.19(\mathrm{t}, 7.9)$ & 123.1 & C-5, C-8a & $7.21(\mathrm{t}, 7.9)$ & 123.1 & C-5, C-8a & $7.21(\mathrm{t}, 7.1)$ & 123.0 & $C-5, C-8 a$ \\
\hline 8 & $\begin{array}{l}7.84(\mathrm{dd}, 7.8 \text { and } \\
1.4)\end{array}$ & 117.9 & C-9, C-10a, C-6 & $\begin{array}{l}7.85(\mathrm{dd}, 7.8 \text { and } \\
1.6)\end{array}$ & 117.8 & $\begin{array}{l}\text { C-9, C-10a, } \\
\text { C-6 }\end{array}$ & $\begin{array}{l}7.89(\mathrm{dd}, 7.1 \text { and } \\
1.9)\end{array}$ & 117.8 & C-6, C-9 \\
\hline $8 \mathrm{a}$ & & 124.2 & & & 124.0 & & & 123.7 & \\
\hline $9 \mathrm{a}$ & & 107.4 & & & 112.7 & & & 116.1 & \\
\hline 9 & & 175.2 & & & 176.4 & & & 176.3 & \\
\hline $1^{\prime}$ & $4.63(\mathrm{~d}, 6.3)$ & 66.3 & $\mathrm{C}-1, \mathrm{C}-2^{\prime}, \mathrm{C}-3^{\prime}$ & $4.68(\mathrm{~d}, 5.7)$ & 66.4 & $\begin{array}{l}\mathrm{C}-2^{\prime}, \mathrm{C}-3^{\prime}, \mathrm{C}- \\
1\end{array}$ & $4.56(\mathrm{~d}, 7.1)$ & 71.5 & $\mathrm{C}-1, \mathrm{C}-2^{\prime}, \mathrm{C}-3^{\prime}$ \\
\hline $2^{\prime}$ & $5.57(\mathrm{t}, 6.3)$ & 119.4 & & $5.57(t, 5.7)$ & 119.3 & & $5.71(\mathrm{t}, 7.1)$ & 120.5 & \\
\hline $3^{\prime}$ & & 137.5 & & & 137.6 & & & 137.8 & \\
\hline $4^{\prime}$ & $1.80(\mathrm{~s})$ & 25.8 & $\mathrm{C}-5^{\prime}, \mathrm{C}-3^{\prime}, \mathrm{C}-2^{\prime}$ & $1.80(\mathrm{~s})$ & 25.8 & $\begin{array}{l}\mathrm{C}-5^{\prime}, \mathrm{C}-3^{\prime}, \mathrm{C}- \\
2^{\prime}\end{array}$ & $1.80(\mathrm{~s})$ & 25.8 & $\mathrm{C}-5^{\prime}, \mathrm{C}-3^{\prime}, \mathrm{C}-2^{\prime}$ \\
\hline $5^{\prime}$ & $1.76(\mathrm{~s})$ & 18.4 & $\mathrm{C}-4^{\prime}, \mathrm{C}-3^{\prime}, \mathrm{C}-2^{\prime}$ & $1.75(\mathrm{~s})$ & 18.3 & $\begin{array}{l}\mathrm{C}-4^{\prime}, \mathrm{C}-3^{\prime}, \mathrm{C}- \\
2^{\prime}\end{array}$ & $1.77(\mathrm{~s})$ & 18.1 & $\mathrm{C}-4^{\prime}, \mathrm{C}-3^{\prime}, \mathrm{C}-2^{\prime}$ \\
\hline $1^{\prime \prime}$ & $4.58(\mathrm{~d}, 6.8)$ & 66.3 & $\mathrm{C}-3, \mathrm{C}-2^{\prime \prime}, \mathrm{C}-3^{\prime \prime}$ & $4.70(\mathrm{~d}, 4.2)$ & 66.4 & $\begin{array}{l}\mathrm{C}-5, \mathrm{C}-2^{\prime \prime}, \mathrm{C}- \\
3^{\prime \prime}\end{array}$ & $3.45(\mathrm{~d}, 7.2)$ & 27.7 & $\begin{array}{l}\mathrm{C}-1, \mathrm{C}-2, \mathrm{C}-3, \mathrm{C}-2^{\prime \prime}, \\
\mathrm{C}-3^{\prime \prime}\end{array}$ \\
\hline $2^{\prime \prime}$ & $5.52(\mathrm{t}, 6.8)$ & 118.4 & & $5.62(\mathrm{t}, 4.2)$ & 119.4 & & $5.30(\mathrm{t}, 7.2)$ & 122.5 & \\
\hline $3^{\prime \prime}$ & & 139.4 & & & 138.6 & & & 133.1 & \\
\hline $4^{\prime \prime}$ & $1.76(\mathrm{~s})$ & 25.8 & $\mathrm{C}-5^{\prime \prime}, \mathrm{C}-2^{\prime \prime}, \mathrm{C}-3^{\prime \prime}$ & $1.78(\mathrm{~s})$ & 25.9 & $\begin{array}{l}\mathrm{C}-5^{\prime \prime}, \mathrm{C}-2^{\prime \prime} \\
\mathrm{C}-3^{\prime \prime}\end{array}$ & $1.74(\mathrm{~s})$ & 25.9 & $\mathrm{C}-5^{\prime \prime}, \mathrm{C}-2^{\prime \prime}, \mathrm{C}-3^{\prime \prime}$ \\
\hline $5^{\prime \prime}$ & $1.72(\mathrm{~s})$ & 18.3 & $\mathrm{C}-4^{\prime \prime}, \mathrm{C}-2^{\prime \prime}, \mathrm{C}-3^{\prime \prime}$ & $1.74(\mathrm{~s})$ & 18.4 & $\begin{array}{l}\mathrm{C}-4^{\prime \prime}, \mathrm{C}-2^{\prime \prime}, \\
\mathrm{C}-3^{\prime \prime}\end{array}$ & $1.71(\mathrm{~s})$ & 17.8 & $\mathrm{C}-4^{\prime \prime}, \mathrm{C}-2^{\prime \prime}, \mathrm{C}-3^{\prime \prime}$ \\
\hline $1^{\prime \prime \prime}$ & $4.70(\mathrm{~d}, 6.6)$ & 66.4 & C-5, C-2 $2^{\prime \prime \prime}, C-3^{\prime \prime \prime}$ & & & & $4.71(\mathrm{~d}, 6.5)$ & 66.4 & $\mathrm{C}-5, \mathrm{C}-2^{\prime \prime \prime}, \mathrm{C}-3^{\prime \prime \prime}$ \\
\hline $2^{\prime \prime \prime}$ & $5.62(\mathrm{t}, 6.6)$ & 119.4 & & & & & $5.59(\mathrm{t}, 6.5)$ & 119.2 & \\
\hline $3^{\prime \prime \prime}$ & & 138.4 & & & & & & 138.6 & \\
\hline $4^{\prime \prime \prime}$ & $1.80(\mathrm{~s})$ & 25.8 & $\begin{array}{l}\mathrm{C}-5^{\prime \prime \prime \prime}, \mathrm{C}-2^{\prime \prime \prime} \\
\mathrm{C}-3^{\prime \prime \prime}\end{array}$ & & & & $1.69(\mathrm{~s})$ & 25.9 & $\mathrm{C}-5^{\prime \prime \prime}, \mathrm{C}-2^{\prime \prime \prime}, \mathrm{C}-3^{\prime \prime \prime}$ \\
\hline $5^{\prime \prime \prime}$ & $1.75(\mathrm{~s})$ & 18.4 & $\begin{array}{l}\mathrm{C}-4^{\prime \prime \prime}, \mathrm{C}-2^{\prime \prime \prime} \\
\mathrm{C}-3^{\prime \prime \prime}\end{array}$ & & & & $1.62(\mathrm{~s})$ & 18.4 & $\mathrm{C}-4^{\prime \prime \prime}, \mathrm{C}-2^{\prime \prime \prime}, \mathrm{C}-3^{\prime \prime \prime}$ \\
\hline
\end{tabular}

${ }^{1} \mathrm{H}$ connectivities were determined by using the COSY experiment. One-bond ${ }^{1} \mathrm{H}-{ }^{13} \mathrm{C}$ connectivities were determined with HMQC gradient pulse factor selection. Two and three bond ${ }^{1} \mathrm{H}^{13} \mathrm{C}$ connectivities were determined by HMBC experiment. Chemical shifts were reported in $\delta(\mathrm{ppm})$ and coupling constants $(J)$ were measured in $\mathrm{Hz}$. TLC was performed on precoated silica gel cards (E. Merck), spots were viewed under ultraviolet light at $254 \mathrm{~nm}$ for fluorescence quenching spots and at $366 \mathrm{~nm}$ for fluorescent spots and stained by spraying with a solution of ceric sulphate $(0.2 \%)$ in $\mathrm{H}_{2} \mathrm{SO}_{4}(5 \%)$. For column chromatography, silica gel (E. Merck, 230-400 mesh) were used. All reagents used were of analytical grades.

\subsection{Plant material}

The wood trunk of $G$. polyantha was collected from Mt Kala, central-province Cameroon in August 2003, and identified by Dr. Tchiengue Bathelemy of the Cameroon Nation Herbarium (Yaoundé), where a voucher specimen (21337/SRF/Cam/Mt Kala) was deposited.

\subsection{Extraction and isolation}

Air dried and ground wood trunk of $G$. polyantha $(3.5 \mathrm{~kg}$ ) was macerated in methanol for three days at room temperature and the fractions were concentrated under reduce pressure to yield $83 \mathrm{~g}$ of methanol extract. The methanol extract was subjected to column chromatography eluting with hexane, hexane- $\mathrm{CH}_{2} \mathrm{Cl}_{2}, \mathrm{CH}_{2} \mathrm{Cl}_{2}-\mathrm{MeOH}$ in increasing order of polarity to afford fractions A-D. The mixture of fraction A and B (4.2 g) obtained with Hexane- $\mathrm{CH}_{2} \mathrm{Cl}_{2}$ (9.5:0.5 and 8.5:1.5, respectively) was purified by column chromatography over silica gel $(5 \times 80 \mathrm{~cm})$ eluted with a mixture of hexane- $\mathrm{CH}_{2} \mathrm{Cl}_{2}$ in increasing order of polarity to yield compounds $\mathbf{1}(16 \mathrm{mg}), \mathbf{4}(122 \mathrm{mg})$ and 


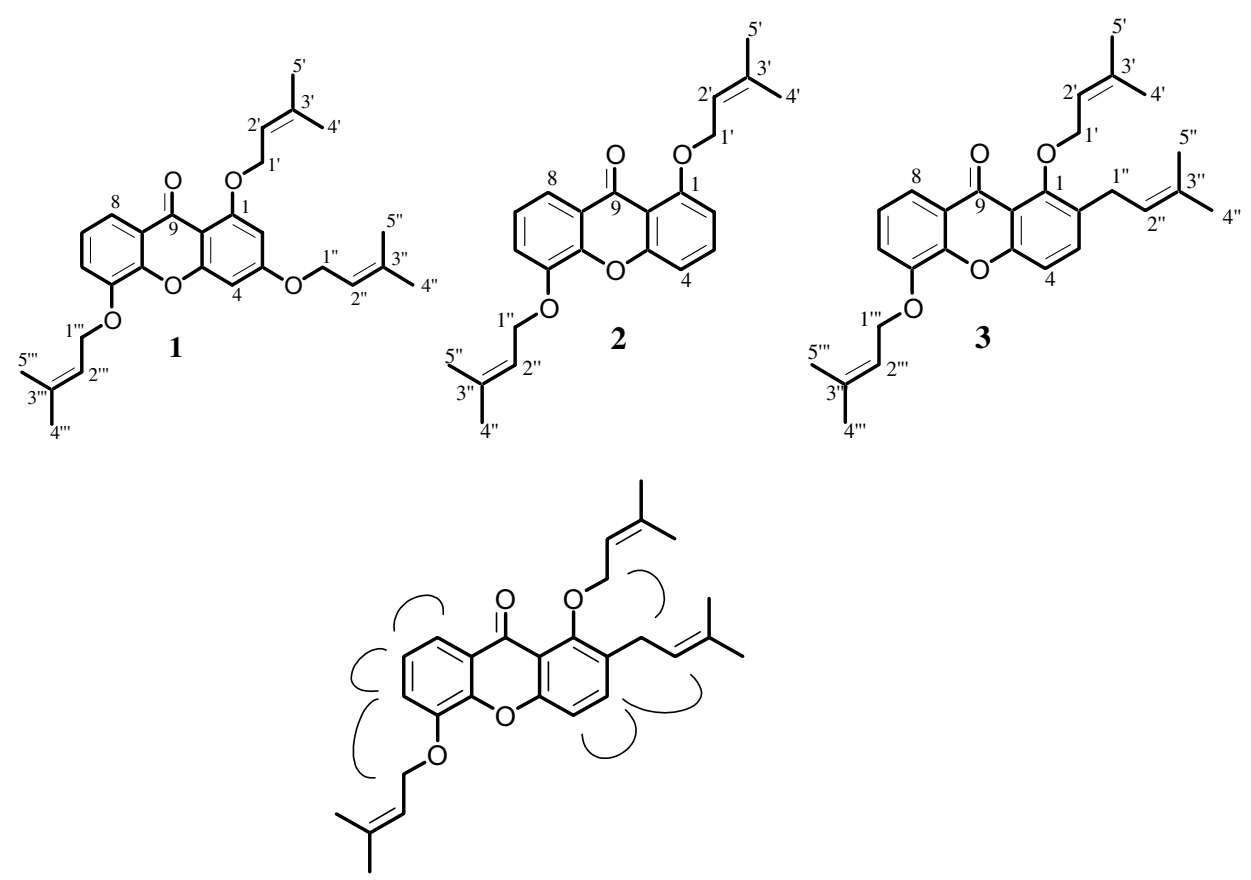

Fig. 1. NOESY correlations of $\mathbf{3}$.

three sub fractions $\left(\mathrm{B}_{1}-\mathrm{B}_{3}\right)$. The sub fraction $\mathrm{B}_{2}(1.4 \mathrm{~g})$ obtained with hexane- $\mathrm{CH}_{2} \mathrm{Cl}_{2}$ (9.0:1.0) was further purified by silica gel column chromatography $(3 \times 50 \mathrm{~cm})$ with hexane- $\mathrm{CH}_{2} \mathrm{Cl}_{2}(9.3: 0.7)$ to give compound $2(15 \mathrm{mg})$ and $\mathbf{5}$ (47 $\mathrm{mg}$ ), and the sub fraction $\mathrm{B}_{1}$ was purified by preparative TLC (hexane- $\mathrm{CH}_{2} \mathrm{Cl}_{2}$ (9.5:0.5) to give compound 3 $(14 \mathrm{mg})$. Fraction $\mathrm{C}(1.6 \mathrm{~g})$ obtained with hexane- $\mathrm{CH}_{2} \mathrm{Cl}_{2}$ $(8.0: 2.0)$ was purified by column chromatography over silica gel $(3 \times 50 \mathrm{~cm})$ eluted with a mixture of hexane- $\mathrm{CH}_{2} \mathrm{Cl}_{2}$ in increasing order of polarity to yield compounds 6 $(14 \mathrm{mg}), 8(14 \mathrm{mg})$ and $7(37 \mathrm{mg})$. Finally, fraction D was found to contain mainly very polar compounds.

\subsubsection{Polyanxanthone A (1)}

Whitish crystal, m.p.: $135-137^{\circ} \mathrm{C}$. UV $(\mathrm{MeOH}) \lambda \max$ $\left(\log ^{\varepsilon}\right): 303$ (2.5), 247 (3.04), 202 (3.03), 275 (2.35), 225 (2.75). IR (KBr) $v_{\max } \mathrm{cm}^{-1} 3626,2914,1656,1601,1289$, 1159, 1101, 956, 670. EIMS: $m / z 448\left[\mathrm{M}^{+}\right]$(6.86), 379 (4), 312 (16), 244 (69), 228 (4), 69 (100). HR-EIMS: $m / z$ 448.2277 (calc. 448.2250 for $\left.\mathrm{C}_{28} \mathrm{H}_{32} \mathrm{O}_{5}\right) .{ }^{1} \mathrm{H}(500 \mathrm{MHz})$ and ${ }^{13} \mathrm{C}(125 \mathrm{MHz}) \mathrm{NMR}$, see Table 1.

\subsubsection{Polyanxanthone B (2)}

White crystal; m.p.: $139.9-140{ }^{\circ} \mathrm{C}$. UV $(\mathrm{MeOH}) \lambda \max$ $\left(\log ^{\varepsilon}\right): 353$ (2.53), 303 (2.6), 246 (3.24), 202 (3.09). IR (KBr) $v_{\max } \mathrm{cm}^{-1} 3629,2972,1601,1490,1379,821,767$. EIMS: $m / z 364\left[\mathrm{M}^{+}\right]$(2.1), 296 (6), 228 (100), 119 (37). HR-EIMS: $m / z$ 364.1686 (calc. 364.1675 for $\mathrm{C}_{23} \mathrm{H}_{24} \mathrm{O}_{4}$ ). ${ }^{1} \mathrm{H}(500 \mathrm{MHz})$ and ${ }^{13} \mathrm{C}(125 \mathrm{MHz}) \mathrm{NMR}$, see Table 1.

\subsubsection{Polyanxanthone $C(\mathbf{3})$}

Yellow oil. UV $(\mathrm{MeOH}) \lambda \max \left(\log ^{\varepsilon}\right): 389$ (2.05) 340 (1.70), 297 (2.08), 255 (2.86), 203 (3.05). IR (KBr) $v_{\max } \mathrm{cm}^{-1} 3566,2972,1656,1566,1432,1268,1227,1101$, 956, 767. EIMS: $m / z 432\left[\mathrm{M}^{+}\right]$(2.07) 364 (10), 296 (34), 253 (25), 241(77), 69 (100). HR-EIMS: $m / z 432.1234$ (calc. 432.1237 for $\left.\mathrm{C}_{28} \mathrm{H}_{32} \mathrm{O}_{4}\right) .{ }^{1} \mathrm{H}(500 \mathrm{MHz})$ and ${ }^{13} \mathrm{C}(125 \mathrm{MHz})$ NMR, see Table 1.

\subsection{Anticholinesterase assays}

Electric-eel AChE (EC 3.1.1.7), horse-serum BChE (EC 3.1.1.8), acetylthiocholine iodide, butyrylthiocholine chloride, 5,5'-dithio-bis-nitrobenzoic acid (DTNB) and galanthamine were purchased from the Sigma (St. Louis, MO, USA). All other chemicals were of analytical grade. AChE and $\mathrm{BChE}$ inhibiting activities were measured by the spectrophotometric method developed by Ellman (Ellman et al., 1961). Acetylthiocholine iodide and butyrylthiocholine chloride were used as substrates to assay AChE and $\mathrm{BChE}$, respectively. The reaction mixture contained $130 \mu 1(100 \mathrm{mM})$ sodium phosphate buffer ( $\mathrm{pH} 8.0), 20 \mu 1$ of DTNB, $10 \mu \mathrm{l}$ of test compound solution and $20 \mu \mathrm{l}$ of $\mathrm{AChE}$ or BChE solution, which were mixed and incubated for $15 \mathrm{~min}$ at $25^{\circ} \mathrm{C}$. The reaction was then initiated by the addition of $20 \mu \mathrm{l}$ acetylthiocholine or butyrythiocholine, respectively. The hydrolysis of acetylthiocholine and butyrylthiocholine were monitored by the formation of yellow 5-thio-2-nitrobenzoate anion as a result of the reaction of DTNB with thiocholine, released by the enzymatic hydrolysis of acetylthiocholine and butyrylthiocholine, respectively at a wavelength of $412 \mathrm{~nm}(15 \mathrm{~min})$. Test compounds and the positive control (galanthamine) were dissolved in EtOH. All the reactions were performed in triplicate in 96-well micro-plates in SpectraMax 340 (molecular Devices, USA). The concentrations of test 
compounds that inhibited the hydrolysis of substrates (acetylthiocholine and butyrylthiocholine) by 50\% ( $\left.\mathrm{IC}_{50}\right)$ were determined by monitoring the effect of increasing concentrations of these compounds in the assays on the inhibition values. The $\mathrm{IC}_{50}$ values were then calculated using the EZ-Fit Enzyme Kinetics program (Perrella Scientific Inc., Amherst, USA.).

\section{Acknowledgements}

One of us, A. Meli Lannang wishes to acknowledge Third World Academy of Science (TWAS) for Postdoc. fellowship to the HEJ Research Institute of Chemistry, University of Karachi, Pakistan and TWAS Research Grand No. 05-148 RG/CHE/AF/AC.

\section{References}

Ampofo, A.S., Waterman, G.P., 1986. Xanthones from three Garcinia species. Phytochemistry 25, 2351-2355.

Brehaut, J., 1975. Flore illustrée du Sénégal. Gouvernement du Sénégal, ministère du développement rural et de l'hydraulique, direction des eaux et forêt, Dakar, pp. 89-90.

Carpenter, I., Locksley, H.D., Scheinmann, F., 1969. Xanthones in higher plants: biogenetic proposals and a chemotaxonomic survey. Phytochemistry 8, 2013-2015.

Deachathai, S., Mahabubarakam, W., Phongpaichit, S., Taylor, W.C., Zhang, Y.-J., Yang, C.-R., 2006. Phenolic Compounds from the flowers of Garcinia dulcis. Phytochemistry 67, 464-469.
Ellman, G.L., Courtney, D., Andres, V., Featherstone, R.M., 1961. A new and rapid colorimetric determination of acetylcholinesterase activity. Blochem. Pharmacol. 7, 88-95.

Frahm, A.W., Chandhuri, R.K., 1979. Carbon-13 NMR spectroscopy of substituted xanthones II. Carbon-13 NMR spectral study of polyhydroxyxanthones. Tetrahedron 35, 2035-2038.

Ito, C., Itoigawa, M.C., Takakura, T., Ruangrungsi, N., Enjo, F., Tokuda, H., Nishino, H., Furukawa, H., 2003. Chemical constituents of Garcinia fusca: structure elucidation of eight new xanthones and their cancer chemopreventive activity. J. Nat. Prod. 66, 200-205.

Kanda, P., Pongcharoen, W., Phongpaichit, S., Walter, C.T., 2006. Tetraoxygenated xanthones from the fruits of Garcinia Cowa. Phytochemistry 67, 999-1004.

Komguem, J., Meli, A.L., Manfouo, R.N., Lontsi, D., Ngounou, F.N., Kuete, V., Kamdem, W.H., Tane, P., Ngadjui, B.T., Sondengam, B.L., Connelly, J.D., 2005. Xanthones from Garcinia smeathmannii (Oliver) and their antimicrobial activity. Phytochemistry 66, 1713-1717.

Meli, A.L., Komguem, J., Ngounou, F.N., Tangmouo, J.G., Lontsi, D., Ajaz, A., Iqbal, M.C., Ranjit, R., Devkota, K.P., Sondengam, B.L., 2005. Bangangxanthone A and B, two xanthones from the stem bark of Garcinia polyantha Oliv. Phytochemistry 66, 2351-2355.

Nilar, L.-H., Nguyen, D., Ganpathi, V., Sim, k.-Y., Harrison, L.J., 2005. Xanthones and benzophenones from Garcinia griffithii and Garcinia mangostana. Phytochemistry 66, 1718-1723.

Nkengfack, E.A., Mkounga, P., Fomum, T.Z., Meyer, M., Bodo, B., 2002. Globulixanthones A and B, two new cytotoxic xanthones with isoprenoid groups from the root bark of Symphonia globulifera. J. Nat. Prod. 65, 734-736.

Williams, R.B., Hoch, J., Glass, T.E., Evans, R., Miller, J.S., Wisse, J.H., Kingstone, D.G.I., 2003. A novel cytotoxic guttiferone analogue from Garcinia macrophylla from the Surinam rainforest. Planta Med. 69, 864-866.

Zhang, Z., Elsohly, H.N., Jacob, M.R., Pasco, D.S., Walter, L.A., Clark, A.M., 2002. Natural products inhibiting Candida albicans secreted aspartic proteases from Tovomita krukovii. Planta Med. 68, 49-50. 